\title{
ACCIONES PARALELAS Y MONTAJE ACELERADO EN EL SEGUNDO EPISODIO DE HORA O
}

\author{
POR \\ ROBERT PRING-MILL \\ St. Catherine's College, Oxford
}

\begin{abstract}
Parallel action. A device of narrative in which two scenes are observed in parallel by crosscutting. Also called parallel montage. See accelerated montage.

Accelerated montage. A sequence edited into progressively shorter shots to create a mood of tension and excitement.
\end{abstract}

James Monaco, How to read a film ${ }^{2}$.

Al prologar la versión inglesa de sus 'poemas documentales' (el término es mío) propuse varios paralelos entre los recursos poéticos de Ernesto Cardenal y determinados aspectos del montaje cinematográfico ${ }^{2}$. No se trataba de ninguna búsqueda de influencias directas del cine sobre su poesía, sino de señalar ciertas coincidencias de las cuales el poeta estaba bien consciente (habíamos hablado largamente de algunas de ellas en Solentiname en 1972). Las destaqué así para hacer resaltar mejor el carácter eminentemente visual de su poesía, porque los paralelos entre estos poemas documentales y el arte fílmico nos pueden ayudar a comprender precisamente cómo funcionan varios de sus recursos contrastivos y asociativos predilectos ${ }^{3}$. Hoy vuelvo al mismo tema, pero para estudiar un

${ }^{1}$ (Nueva York, 1977), p. 421, p. 395. Debo los equivalentes de estos y otros términos cinematográficos a mi amigo Vicente Molina Foix, gran crítico de cine; pero hay algunos, como flashback, que no parecen tener equivalentes españoles de aceptación general hasta el momento.

${ }^{2}$ Robert Pring-Mill, "The Redemption of Reality through Documentary Poetry", en Ernesto Cardenal, Zero Hour and Other Documentary Poems (Nueva York, 1980), pp. IX-XxI. Ahí se explican los orígenes del término, acuñado en 1972 para distinguir Hora 0 (1954-1956) y Canto nacional (1970-1972) de los otros tipos de poesía que Cardenal había escrito entre aquellos dos (véase op. cit., p. x).

${ }^{3}$ Para un estudio de tales recursos 'contrastivos' y 'asociativos', véase la tesis inédita de Paul W. Borgeson, Ir., The Poetry of Ernesto Cardenal (Ph. D. dissertation, Vanderbilt University, 1977), de próxima aparición en español en México. 
ejemplo específico de modo más detenido: una sección del episodio dedicado a Sandino en Hora 0 , en cuya parte central (cuyo carácter fílmico ya se ha indicado anteriormente) ${ }^{4}$ se combinan los dos tipos de montaje indicados en el título de este trabajo. Otros de sus recursos típicos se comentarán al mismo tiempo, y el mismo texto también dará lugar para algunas reflexiones sobre su modo de tratar los hechos históricos cuando está transmutando la historia en poesía.

Quien primero señalara el carácter fílmico de su poesía fue José Coronel Urtecho, en su larga 'carta prólogo' a El estrecho dudoso, refiriéndose al ritmo de la composición, cuando la elogió por «la rápida técnica alucinante de una película documental, que es, a mi juicio, la técnica apropiada para una nueva épica» ${ }^{5}$. Mientras el mismo Cardenal emplearía la analogía del montaje cinematográfico cuando quiso explicar las enseñanzas de su maestro Ezra Pound, al fin de un largo párrafo sobre la doctrina poundiana del ideograma:

o sea el descubrimiento de que la poesía se escribe exactamente en la misma forma que el ideograma chino, es decir, a base de superposición de imágenes... La de Pound es una poesía directa; consiste en contraponer imágenes, dos cosas contrarias o bien dos cosas semejantes que al ponerse una al lado de la otra producen una tercera imagen. Por ejemplo, cuando Pound contrapone la imagen de las putas y la del santuario de Eleusis, dos cosas tan contradictorias. Juntándolas, produce la tercera imagen: la usura ha llevado putas a Eleusis... [Así] es como los chinos escriben, porque la lengua china es, según Pound, esencialmente poética. En cambio, nosotros estamos acostumbrados a otro tipo de lenguaje, y sólo a través de la poesía podemos expresarnos como los chinos con el ideograma, es decir, mediante la superposición de imágenes. Es también lo que hace el cine con los montajes de imágenes ${ }^{6}$.

E1 paralelo cinematográfico hace resaltar el carácter visual del recurso poético mejor que la analogía del ideograma chino, en la verdad, aunque

${ }^{4}$ Véase la tesis inédita de J. J. Lyons, Ernesto Cardenal: The Poetics of Love and Revolution (Ph. D. dissertation, London, 1979), p. 20; el episodio de Sandino se comenta en las pp. 15-24. No siempre coincidimos, pero el análisis de Lyons es valiosísimo. Es de esperar que esta tesis se publique pronto.

${ }^{5}$ El estrecho dudoso (Madrid, 1969), p. 31; el texto de esta carta en la edición de EDUCA ( Primera Edición», San José de Costa Rica, 1971) registra ligeros cambios, pero ellos no afectan esta cita.

- Mario Benedetti, Los poetas comunicantes (Montevideo, 1972), pp. 101-102; la entrevista con Cardenal (La Habana, enero de 1970) se titula «Ernesto Cardenal: evangelio y revolución». Para la influencia de Pound, véase Isabel Fraire, «Pound and Cardenal» (Review, No. 18, 1976), pp. 36-42. 
el tipo de montaje aludido no es - propiamente dicho- el de la superposición (en que dos imágenes se superponen en el mismo encuadre para ser proyectadas simultáneamente sobre la pantalla), sino más bien el del montaje dialéctico, o montaje de choque (es decir, collisional montage), en que la sucesión de dos imágenes visibles produce otra más en la mente del espectador. Por consiguiente, yo preferiría hablar de la yuxtaposición de imágenes: de hecho, sería imposible 'proyectarlas' simultáneamente en la poesía, puesto que un texto tiene que leerse 'en el tiempo', mientras que la auténtica 'superposición' de imágenes es fácil de conseguir en la pantalla.

El montaje dialéctico de imágenes es sin duda el recurso más característico de la poesía de Cardenal. El 'introito' de Hora 0 (verdadera composición de lugar ignaciana, que en términos fílmicos sería una secuencia de establishing shots) está construido casi enteramente a base de tales yuxtaposiciones; por ejemplo:

En su palacio como un queque rosado

Ubico está resfriado. Afuera el pueblo fue dispersado con bombas de fósforo ${ }^{7}$.

En esta ocasión quisiera ocuparme más bien del segundo de sus tres episodios para destacar el empleo de dos procedimientos 'fílmicos' que repiten la misma técnica de contraposición dialéctica en escala mayor, verbigracia, la narración de acciones paralelas contrastantes por medio del montaje en paralelo que las va entrecortando, reforzado en la sección de mayor intensidad emotiva por el montaje acelerado, en que el ritmo de la alternación entre las dos acciones se va acelerando progresivamente para producir una siempre creciente expectativa ansiosa en la mente del lector/espectador ${ }^{8}$.

El segundo episodio de Hora 0 cuenta la vida y la muerte de San-

${ }^{7}$ Versos 8-10. Salvo indicaciones en contrario, las citas de Hora 0 siguen su primera edición en folleto aparte (México, 21 de febrero de 1960), cuyo colofón sigue hablando de «estos poemas» (como tales, habían figurado en dos entregas de la Revista Mexicana de Literatura, enero-abril de 1957 [Nos. 9-10] y abril-junio de 1959 [No. 2]). Se lo trata como un solo poema en La hora 0 (Poesía, Montevideo, 1966, $32 \mathrm{pp}$.); hay ligeras diferencias entre estos textos, así como entre ellos y el texto en E. Cardenal, Antología, Buenos Aires, 1971. Para las circunstancias de su composición, véase Pring-Mill, op. cit., pp. xvii-xix.

${ }^{8}$ Lyons, después de citar el mismo pasaje de la entrevista de 1970 (terminando con «la usura ha llevado putas a Eleusis»), dice: «On a larger scale the same procedure can be employed by cross-cutting from one scene to another, just as in the cinema a director is able to keep several threads developing separately until he wishes to bring them together or offer a contrast», op. cit., p. 7. 
dino. Es largo — doscientos ochenta y ocho versos (vv. 145-393) - y sólo se analizará su segunda sección: la que va desde que «Se firmó el desarme» (v. 279) del ejército de Sandino hasta su asesinato la noche del 21 de febrero de 1934, durante la presidencia de Sacasa, fusilado en secreto y a traición por orden del general Somoza García (el que iba a ser el primer Somoza tirano), instalado por los norteamericanos como jefe director de la Guardia Nacional el año anterior ${ }^{9}$. Esta sección tiene tres partes: las cinco estrofas (vv. 279-300) que preceden el comienzo de las acciones paralelas; diez estrofas de las acciones paralelas propiamente dichas (vv. 301-359, con montaje acelerado en la Acción B), y algo a manera de 'epílogo' que consiste en una larga tirada de veinticinco versos (vv. 360-384), seguido por tres estrofas mucho más breves (vv. 385-393). Cada una de estas partes se transcribirá entera, para que se pueda ver su estructura visual sobre la página antes de comentarla.

\section{PRIMERA PARTE}

(1)

Se firmó el desarme. Cargaron las armas en carretas.

280 Guatuceros amarrados con cabuyas, rifles sarrosos

y unas cuantas ametralladoras viejas.

$\mathrm{Y}$ las carretas van bajando por la sierra.

Si por mar en un buque de guerra

Telegrama del Ministro Americano (Mr. Lane)

al Secretario de Estado - Depositado en Managua

el 14 de febrero de 1934 a las 6:5 p. m.

288 y recibido en Washington a las 8:50 p. m.:

«Informado por fuente oficial

que el avión no pudo aterrizar en Wiwilí

y por tanto la venida de Sandino se retrasa...»

(4) 292 E1 telegrama del Ministro Americano (Mr. Lane)

al Secretario de Estado el 16 de febrero

9 Para los hechos históricos, véase Neill Macaulay, The Sandino Affair, 1967 (cit. por la edición de Chicago, 1971), y Richard Millett, Guardians of the Dynasty (Maryknoll, 1977), cuyas versiones representan necesariamente una confrontación de muchas fuentes, incluyendo la documentación norteamericana existente en el Archivo Nacional de los Estados Unidos (publicada sólo parcialmente por el Departamento de Estado en la serie Papers Relating to the Foreign Relations of the United States) y las publicaciones de muchos de los participantes. 
anunciando la llegada de Sandino a Managua Not Printed

296 no fue publicado en la memoria del Depto. de Estado.

Como la guardatinaja que salió del matorral a la carretera y es acorralada por los perros y se queda parada delante de los tiradores

300 porque sabe que no tiene para dónde correr...

\section{Comentario a la Primera parte}

(1) Esta estrofa es una breve secuencia descriptiva, cuya primera frase es puramente contextual: sería fácil formarnos una imagen visual de la firma del tratado (basada en nuestros recuerdos de muchas fotos de ocasiones parecidas), pero no estamos obligados a visualizarla, dada la ausencia de cualquier indicación visual en las palabras. En cambio, el resto del cuarteto no contiene más que imágenes visuales ${ }^{10}$, las cuales tienen toda la apariencia de las indicaciones de un guión: a) las carretas como en plano medio; b) las armas en primer plano (closeup), con c) algunos detalles de su vejez en gran primer plano (detail shot); y entonces la cámara se retira para $d$ ) un plano general (long shot) de carretas «bajando por la sierra».

(2) Sigue la cuarta cita de "Adelita» (canción de la revolución mexicana que ha jugado el papel de theme song en escenas anteriores, a partir del v. 209). El uso repetido de tales citas es también un elemento de carácter fílmico, empleado para comunicarnos el espíritu entusiasta de las fuerzas guerrilleras ( $U$ Un ejército alegre, con guitarras y con abrazos. / Una canción de amor era su himno de guerra», vv. 207-208). Primero se citó el cuarteto entero ( $\$ S i$ Adelita se fuera con otro, / La seguiría por tierra y por mar, / Si por mar en un buque de guerra, / Y si por tierra en un tren militar», vv. 209-212), y luego hay tres reprises parciales (vv. 272, 277-278, 283-284), de las cuales ésta es la última. Si se tratara

10 «Las más importantes de las imágenes son las visuales; la mayor parte de las cosas nos entran por la vista», dice E. Cardenal en «Unas reglas para escribir poesía» (publicadas en Barricada, 10 de marzo de 1980), cito por el texto mimeografiado distribuido por el Ministerio de Cultura para el uso de los Talleres de Poesía auspiciados por Cardenal, en su capacidad de ministro de Cultura. Véase también Claire Pailler, "Poésie populaire et revolution au Nicaragua» (Iris, Centre de Recherche sur les Littératures Ibériques et Ibéro-Americaines Modernes, Montpellier, No. 1, 1981), pp. 35-61. 
de una película, es de suponer que se escucharía mientras se mirase la bajada de las carretas por la sierra: un poema no permite tales coincidencias temporales, y la cita viene después de las imágenes visuales. Constituye (aunque no lo sabemos todavía) nuestra despedida de los guerrilleros, pero también tiene otra función poética: la de encubrir una condensación poética de los hechos históricos. Quien leyese sólo el poema no se daría cuenta de que más de un año había transcurrido entre la firma del desarme (el 2 de febrero de 1933) y la venida de Sandino a Managua el 16 de febrero de 1934 (cinco días antes de morir): venida cuidadosamente 'documentada' en las dos estrofas siguientes.

(3) Esta es la primera de dos bridging shots documentales (como aquellos breves vistazos de periódicos en Citizen Kane, que no sólo encubren cambios de lugar o tiempo de otro modo demasiado abruptos, sino que también sirven para comunicar alguna información necesaria para la plena comprensión de la siguiente escena). Aquí nos preparan para la llegada de Sandino, mostrándonos dos detalles de la doumentación oficial de la intervención norteamericana tal como éstos figuran en una memoria publicada por el Departamento de Estado. Primero: el telegrama de Mr. Lane diciendo que "la venida de Sandino" se ha retrasado (traducido al español a beneficio de los lectores hispanoparlantes del poema).

(4) Y luego el segundo documento, o más bien la constancia impresa de la ausencia de otro documento (un segundo telegrama de Mr. Lane al secretario de Estado), El Not Printed salta a la vista desde la página (tal como lo haría en la pantalla) sorprendiéndonos, cobrando un fino matiz irónico (bien fuera de las intenciones de los editores del Departamento de Estado) del contraste entre la precisión de los detalles dados y el hecho de callar lo esencial. Además, la yuxtaposición del telegrama puramente informativo anterior con esta referencia tan desnuda al telegrama inédito despierta nuestra curiosidad: ¿por qué no se publicó?, ¿es que habrá dicho algo acerca de lo que se pensaba hacer después (algo que el Departamento de Estado consideró mejor callar)? Cardenal sabe muy bien cómo crear un ambiente de expectativa ominosa para el desenlace trágico que se está preparando entre bastidores, y este sentimiento de presagio comienza de veras con aquel Not Printed, el cual sirve al mismo tiempo para sugerir calladamente la complicidad de los norteamericanos en lo que está por suceder.

(5) Los cuatro versos siguientes intensifican la atmósfera ominosa empleando un recurso más bien poético y bien tradicional (no propiamente 
fílmico, aunque un buen director sabría aprovecharlo, dado su carácter pormenorizadamente visual): un exemplum tomado del mundo natural. Su aplicación al caso de Sandino es obvio: indefenso fuera de su 'matorral' de las Segovias, a punto de hallarse acorralado por «los perros» de Somoza, y que terminará quedándose parado (no solamente inmóvil, como la guardatinaja, sino también erguido) «delante de los tiradores» para morir con dignidad. Al mismo tiempo este símil sirve para reforzar la asociación entre Sandino y la naturaleza: asociación subrayada por el propio Sandino cuando afirmara «En la montaña todo enseña» (v. 259), aunque, para su desgracia, no pensó en la lección de la guardatinaja antes de salir de su propio matorral. Los puntos suspensivos en que termina el exemplum preceden un cambio abrupto de escenario, con el cual se inicia la parte construida a base de las dos acciones paralelas: en la Acción A, se sucede una serie de conversaciones al nivel de las autoridades en Managua, en las que intervendrán Somoza, el ministro americano Mr. Lane y el general Moncada; en la Acción B, las preparativas para la muerte de Sandino, su fusilamiento y su entierro.

\section{SEGUNDA PARTE}

(6) Acción A:

I talked with Sandino for half an hour - dijo Somoza al Ministro Americanobut I can't tell you what he talked about

304 because I don't know what he talked about because I don't know what he talked about.

(7) [sigue]

«Y ya verán que yo no tendré nunca propiedades»... Y: «Es in-cons-ti-tu-cio-nal», decía Sandino.

308 «La Guardia Nacional es inconstitucional.» «An insult!», dijo Somoza al Ministro Americano el VEINTIUNO DE FEBRERo a las 6 de la tarde, «An insult! I want to stop Sandino.»

(8) Acción B: 312 Cuatro presos están cavando un hoyo. «¿Quién se ha muerto?», dijo un preso. «Nadie», dijo el guardia. «Entonces ¿para qué es el hoyo?»

316 «Qué perdés», dijo el guardia, "seguí cavando».

(9) Acción A:

E1 Ministro Americano está almorzando con Moncada. "Will you have coffee, sir?»

Moncada se mantiene mirando a la ventana. 
320 «Will you have coffee, sir?

It's very good coffee, sir.»

"What?» Moncada aparta la mirada de la ventana

y mira al criado: "Oh, yes, I'll have coffee.»

324 Y se rió. «Certainly.»

(10) Acción B:

En un cuartel cinco hombres están en un cuarto cerrado

con centinelas en las puertas y las ventanas.

A uno de los hombres le falta un brazo.

328 Entra el jefe gordo con condecoraciones y les dice: «Yes».

(11) [sigue]

Otro hombre va a cenar esa noche con el Presidente (el hombre para el que estuvieron cavando el hoyo) y les dice a sus amigos: "Vámonos. Ya es hora.»

$332 Y$ suben a cenar con el Presidente de Nicaragua ".

(12) [sigue]

A las 10 de la noche bajan en automóvil a Managua. En mitad de la bajada los detienen los guardias.

A los dos más viejos se los llevan en un auto

336 y a los otros tres en otro auto para otro lado 12.

A donde cuatro presos estuvieron cavando un hoyo. «¿Adónde vamos?»,

preguntó el hombre para el que hicieron el hoyo. Y nadie le contestó.

${ }^{11}$ El texto del folleto mexicano no deja ningún espacio en blanco después del v. 332 (ni lo hay en varias otras ediciones), pero sí hay uno tanto en los Poemas reunidos 1949-1969 (Universidad de Carabobo, 1972) como en la Antología de la Editorial Laia (Barcelona, 1978); en esta ocasión la Antología argentina de 1971 (véase nota 7), habitualmente autoritativa, no nos puede ayudar, pues el v. 333 comienza una nueva página. De hecho, el lapso entre los vv. 332 y 333 parece exigir la pausa.

${ }_{12}$ En el folleto mexicano este verso termina en coma, comenzando el siguiente con minúscula (lectura seguida por las antologías de 1971 y 1978 citadas en la nota anterior); pero La hora 0 uruguaya de 1966 cambia la coma en punto final, comenzando el v. 337 con mayúscula (lectura seguida tanto por la Antología de Cardenal publicada por la Editora Santiago de Chile en 1967 como por el tomo Poemas de Ernesto Cardenal de la colección «La Honda» de Casa de las Américas, La Habana, del mismo año). La lectura de las tres ediciones de los años 19661967 aísla el v. 337 del v. 336, realzándolo (convirtiéndolo en un bridging shot aparte que sirve para ligar de modo más patusado — más dramático- las víctimas que nos han ocupado desde el v. 329 al lugar siniestro visto cuatro estrofas antes). Sería inverosímil suponer que este cambio no se debiera al poeta - aun si otras ediciones posteriores hayan vuelto al texto anterior-. Por estas razones, la lectura de 1966-1967 es la que se ha seguido aquí. 
(13) [sigue]

(14)
Acción A: 344 "I was in a Concierto», dijo Somoza.
$Y$ era cierto, había estado en un concierto
o en un banquete o viendo bailar a una bailarina 0 quién sabe qué mierda sería.
$348 \mathrm{Y}$ a las 10 de la noche Somoza tuvo miedo.
De pronto afuera repicó el teléfono.
« ¡Sandino lo llama por teléfono!»
Y tuvo miedo. Uno de sus amigos le dijo:
352 «No sea pendejo, ijodido!»
Somoza mandó no contestar el teléfono.
La bailarina seguía bailando para el asesino.
$Y$ afuera en la oscuridad siguió repicando

(15) Acción B:

A la luz de una lámpara tubular, cuatro guardias están cerrando un hoyo. $\mathrm{Y}$ a la luz de una luna de febrero.

\section{Comentario a la Segunda parte}

(6) Este primer diálogo al nivel de las autoridades es ahistórico, o mejor dicho, representa otro tipo de condensación poética. En el poema es Somoza quien se está quejando de Sandino al Ministro Americano, pero según las fuentes citadas por Neill Macaulay en The Sandino Affair, sería Salvador Calderón Ramírez (el ministro de Asuntos Exteriores del presidente Sacasa) ${ }^{13}$. Lo que el poeta ha hecho es combinar esta conversación con otra entre Lane y Somoza que tuvo lugar la mañana del 21 de

${ }^{13}$ «The 'highly cultured' Calderón soon appeared 'somewhat disillusioned' with the ex-guerrilla and, in conversations with Minister Lane, "referred in disparaging terms to Sandino's intellectual capacity for expressing his ideas'. Sacasa's Minister of Foreign Affairs [Calderón] told Lane that he had listened carefully to Sandino talk for half an hour, but afterward he had no idea of what the general had been trying to say» (Macaulay, op. cit., pp. 251-252); la nota correspondiente (nota 24, p. 306) nos remite al informe de Lane al secretario de Estado fechado el 20 de febrero de 1934 y a los libros Ultimos dias de Sandino (México, 1934), del propio Salvador Calderón Ramírez, y Los yanquis y Sandino (México, 1962), de Xavier Campos Ponce. 
febrero (el día de la muerte de Sandino), al cual se citará textualmente en la estrofa siguiente. Con esta pequeña modificación de los hechos se han conseguido dos cosas: concentrar el interés sobre la oposición entre Somoza y Sandino y presentar el testimonio de Calderón Ramírez acerca de la 'incomprensibilidad' de la conversación de Sandino como si dicha incomprensión se debiera más bien a los prejuicios de Somoza ${ }^{14}$. El empleo de citas en inglés es típico de Cardenal. Suele tener un sentido irónico, y en el caso de Somoza siempre conlleva el sentido de colocarle en el campo norteamericano, casi como un lacayo del Departamento de Estado.

(7) Esta segunda estrofa empieza con tres versos de citas textuales de lo dicho por Sandino a Somoza, según el poema (pero en la verdad, de lo que aquél dijera a Calderón Ramírez), en la conversación a la cual se refiriera la estrofa anterior, para seguir con citas que, sí, se han tomado de lo dicho por Somoza a Lane el 21 de febrero. Otra vez ha habido una pequeña tergiversación de los hechos para mejorar la 'consecuencialidad' de la narración poética: según Neill Macaulay (condensando un informe de Lane al Departamento de Estado fechado el 22 de febrero), parece que aquel «An insult!» repetido se refería a otra cosa, verbigracia, un intercambio de cartas entre Sandino y el presidente Sacasa en que éste se comprometía a una reorganización de la Guardia Nacional dentro de seis meses y había nombrado un consejero del propio Sandino como delegado presidencial en los departamentos del Norte, lo cual «was an insult to the National Guard and would put the Guardsmen, in the northern departments under the control of Sandino... [Somoza] said he wanted 'to proceed immediately against Sandino' and would 'lock him up' if Lane would 'merely wink [his] eye'» ${ }^{15}$. Es innegable que la reorganización de los datos históricos efectuada por Cardenal resulta mucho más eficaz como poesía de lo que hubiera sido una narración de mayor veracidad histórica. Después del «I want to stop Sandino» se 'corta' desde la primera acción al inicio de la acción paralela.

(8) Viniendo inmediatamente después de aquello, la imagen de «Cuatro presos... cavando un hoyo» (v. 312) es bien siniestra: es obvio que el

14 «The dialogue demonstrates that there can be no communication between a man who symbolizes light and goodness, and another who represents darkness and evil (there is also an echo of Christ's non-communication with Herod and Pilate before the crucifixion)» (Lyons, op. cit., p. 20).

${ }^{15}$ Macaulay, op. cit., p. 252. 
hoyo es una fosa, y el lector/espectador no podrá dejar de asociarla con aquel «I want to stop Sandino», sobre todo cuando la primera contestación del guardia al preso establece que está destinado para alguien que no se ha muerto todavía. Con estos versos se inicia el tono de misterio que habrá de regir todo el progreso de Sandino hacia la muerte: progreso cuya naturaleza trágica se intensifica con la extrema economía narrativa (reforzada por el pequeño recurso de jamás nombrar a «el hombre para el que estuvieron cavando el hoyo», v. 330), suprimiéndose buena cantidad de datos conocidos que se hubieran podido aprovechar, para así hacer resaltar los rasgos más dramáticos ante los ojos del lector/espectador tal como lo hiciera un buen director ante el objetivo de su cámara. Nótese al mismo tiempo cómo el 'voseo' coloquial del guardia en el verso 316 agrega cierto matiz brutalmente irónico a lo enigmático de su segunda intervención.

(9) El poema vuelve a Lane, pero esta vez su interlocutor es otro: José María Moncada, el general que había encabezado una revolución anterior (a la cual se había incorporado Sandino), pero cuya rendición en 1927 -referida en los vv. 160-179- dejó a Sandino como jefe máximo de la guerrilla contra las fuerzas encabezadas por los 'marines' norteamericanos ${ }^{16}$. Dentro del poema sabemos que es enemigo de Sandino a partir del v. 231, el cual nos cuenta cómo - durante la presidencia de Moncada- éste «le llamaba bandido [a Sandino] en los banquetes», lo cual recibiera la contestación burlona: «Claro que no es - dice el Ministro Americano / riendo- pero le llamamos bandolero en sentido técnico» (vv. 237-238). No dejaremos de recordar aquellos «banquetes», unos ochenta versos más tarde, cuando volvemos a encontrar a Moncada reunido en una comida con «el Ministro Americano» (sobre todo porque nada nos indica que ya no se trata del mismo Ministro Americano) ${ }^{17}$.

La preocupación de Moncada en esta nueva escena - preocupación que le «mantiene mirando a la ventana» aparentemente sin oír la primera intervención del criado- sirve para intensificar la tensión. Es natural

${ }^{16}$ Presidente de Nicaragua durante los años 1929-1932, y siempre receloso de la Guardia Nacional, creada por los norteamericanos en 1927, Moncada había cedido el poder al presidente Sacasa el 1 de enero de 1933, el día en que Somoza asumiera el cargo de jefe director de la Guardia Nacional (Somoza siempre había sido el candidato favorecido por Moncada).

${ }^{17}$ Durante la presidencia de Moncada el ministro norteamericano había sido Matthew Hanna; su sucesor como ministro fue Arthur Bliss Lane, el cual llegó a Managua en el mes de diciembre de 1933 (después de un interyalo en que la representación norteamericana había estado en manos del chargé d'affaires Paul C. Daniels). 
suponer que estará pensando en la muerte que se está preparando para Sandino, en el mundo más allá de la ventana [basta la contigüidad de las estrofas (8) y (9) para insinuar su complicidad en el complot]. Dentro de tal contexto, cuando Moncada responde a la segunda intervención del criado, su frase «Oh, yes, I'll have coffee» - $\tan$ natural e inocentecobra un tono siniestro al estar seguida por aquel «Y se rió», el cual nos hace recordar la risa irónica del (otro) Ministro Americano en la comida anterior. De hecho, no parece haber nada que sugiriera que Moncada estuviera históricamente implicado en el complot, y es cierto que Cardenal tampoco dice nada explícito para incriminarle; pero su complicidad no puede sino colegirse de la yuxtaposición de escenas, sobre todo cuando el próximo 'corte' nos habrá de trasladar a una reunión de los conspiradores. Este curioso almuerzo, interpolado, tiene el efecto de incrementar nuestras inquietudes, y la recia certidumbre de su «Certainly» final -el que se refiere tan sólo al querer tomar café- parece transferirse por vías de implicación a la tragedia que se está preparando.

(10) Dentro de la Acción B, el cambio de escena (desde el hoyo al «cuarto cerrado» tan bien defendido en «un cuartel», v. 325) vuelve a intensificar la atmósfera de expectativa inquieta. Tanto lo que se dice como lo que no se dice contribuye a este efecto: es de suponer que se trata de «un cuartel» de la Guardia Nacional, pero el poeta no lo afirma; el faltarle un brazo a uno de los «cinco hombres» (el cual luego habrá de dar la orden «¡Fuego!», aunque esto todavía no se sabe) agrega una nota siniestra, con una ligera sugerencia de que debe de tener motivos de venganza personal (pues es de suponer que haya quedado manco en algún combate con los guerrilleros); igualmente ningún lector/espectador medianamente inteligente dejará de identificar al «jefe gordo con condecoraciones» con el general Somoza, pero su anonimidad le hace más amenazante; y su "Yes» monosilábico y abrupto confirma la existencia de algún plan (no especificado), el cual debe de estar a punto de ponerse en marcha, pero el no saber lo que saben los conspiradores nos deja más inquietos todavía. Todo esto se consigue por haber callado el tipo de detalles que normalmente se dirían, para concentrarse exclusivamente en las imágenes visuales, hasta el momento de dar remate a la escena con aquel «Yes» tajante. Igual que en las escenas anteriores, Cardenal se muestra un maestro de la técnica de aquel "saber callar a tiempo' que nos complace tanto en los romances medievales, y todo lo que no se ha callado aquí queda reducido a meras indicaciones escuetas (como de guión), cuyo efecto cumulativo se debe a su yuxtaposición. 
(11) Cambiamos de escena otra vez, pero siempre dentro de la Acción $B$. Ya hemos visto la fosa; ya hemos visto a los conspiradores de la Guardia; sólo falta la víctima principal y el verle empezando a dirigirse hacia la muerte. Aquella noche del veINTIUNo DE FEBRERo Sandino cenaría con el presidente Sacasa y dos de sus ministros (más dos hermanos del presidente y uno de sus generales) e iría a la cita junto con su padre, don Gregorio Sandino, y con dos de sus propios generales guerrilleros: Juan Pablo Umanzor (nombrado en el v. 217) y Francisco Estrada. Pero la narración, muy sobria, del poeta calla todas las identidades y tampoco nos dirá nada de la cena misma.

(12) Más tarde, a eso de las diez, Sandino, su padre y sus dos generales se despiden del presidente para volver al centro junto con el ministro de Agricultura y Trabajo (Sofonías Salvatierra), en el automóvil de éste. $\mathrm{La}$ interrupción de su viaje de regreso se cuenta en otra estrofa sobria, cada uno de cuyos versos se registra en nuestra vista interior como un plano (shot) distinto, reducidos sus detalles a la mínima indicación posible (cuya economía verbal - y cuya absoluta falta de cualquier adorno- los hace más siniestros todavía). Cuando los guardias dividen el grupo de cinco hombres en dos (uno de dos hombres y el otro de tres), ni siquiera adivinamos en seguida cuál grupo está por morir, incrementándose la duda en nosotros, los lectores, algo como suele crecer (en escala mayor y horripilante) en las mentes de cualquier grupo de detenidos políticos en situaciones parecidas. De hecho, «los dos más viejos» son el padre de Sandino y el ministro Salvatierra (cuyo propio libro Sandino: O la tragedia de un pueblo es una de las fuentes para conocer lo sucedido aquella noche) y los otros tres (Sandino, Estrada y Umanzor) son los que van a ser fusilados allí donde los «cuatro presos estuvieron cavando» anteriormente. Los cambios de ritmo en los últimos tres versos de la estrofa, así como el aislamiento de la pregunta hecha por Sandino, interrumpen la secuencia de versos largos empleados desde que se reanudó la Acción $\mathrm{B}$, mientras la posposición del verso "Y nadie le contestó»" (v. 340) subraya el largo silencio dentro del automóvil de los guardias. Otra larga pausa, antes del desenlace.

(13) Esta estrofa de la muerte es una de las dos más cortas de la Acción B [la otra es la (15), que habrá de rematar la historia de Sandino con su entierro]. Esta Acción B comenzó con una de cinco versos (vv. 312-316); siguió (después del almuerzo de Moncada y Lane) con otra de cuatro versos largos (vv. 325-328, de dieciséis, catorce, once y dieciocho sílabas); la estrofa de la cena con el presidente es parecida, 
también de cuatro versos (vv. 329-332, de dieciséis, catorce, catorce y diecisiete sílabas); la siguiente estrofa, aunque contenga ocho versos (vv. 333-340), se subdivide en otros tantos planos fílmicos, acelerándose el montaje con la brevedad del «¿Adónde vamos?» de Sandino, para culminar en el verso de terminación tan secamente aguda de aquel «Y nadie le contestó». Ahora viene la extremada economía de esta estrofa de tres versos (de catorce, siete y catorce sílabas), cambiándose de nuevo el ritmo con el impacto de las dos palabras agudas del primero de ellos («Después», "paró»), lo cual contribuye mucho (junto con la puntuación, y con la brevedad de las únicas palabras pronunciadas: «Salgan», «زFuego!») al carácter de finalidad definitiva y absoluta del desenlace trágico. Pero el entrecortar (cross-cutting) entre nuestras dos acciones no se ha terminado todavía.

(14) Se vuelve a la Acción A para escuchar lo que Somoza habría de decir después (v. 344), lo cual acarrea tres versos de sarcasmo creciente por parte del narrador, seguidos por un largo flashback de nueve versos (vv. 348-356) que se refieren a una llamada telefónica hecha por el general Sandino (según el v. 350) a la hora en que sabemos que salía rumbo hacia Managua: se insiste en la coincidencia repitiendo la misma frase adverbial ( $A$ A las 10 de la noche bajan en automóvil...», v. 333; «Y a las 10 de la noche Somoza tuvo miedo. / De pronto afuera repicó el teléfono», vv. 348-349). Pudiéramos dudar en un principio de si la llamada se hubiera hecho antes o después de abandonar el palacio, aunque la frase «De pronto» sugiere la segunda alternativa, pero no hay duda de que Somoza «tuvo miedo» antes de que repicara el teléfono; de modo que su miedo tiene que haber sido provocado por su conocimiento de lo que iba a suceder a aquella hora ${ }^{18}$. De todos modos, esta referencia a una llamada de Sandino nos tiene que resultar sorprendente. ¿Qué es lo que había ocurrido, históricamente hablando? Y ¿por qué se habría postergado su poetización?

De hecho, cuando los guardias detuvieron el auto de Salvatierra a la salida de los jardines del palacio y obligaron a bajar a los tres generales sandinistas, parece que Sandino se había dirigido al capitán Delgadillo ${ }^{19}$

${ }^{18}$ "The sense of fear and guilt at the murder of a good man is reminiscent of Herod's execution of John the Baptist; the dancer recalls Salome ("La bailarina seguía bailando para el asesino') and the association of hedonistic pleasure with violence identifies Somoza's sadistic nature» (Lyons, op. cit., p. 21).

${ }^{19}$ Macaulay le llama «Major Lisandro Delgadillo» (op. cit., p. 254), pero uno de sus cómplices lo describe como «Capitán Lizandro Delgadillo, jefe de la $15 .^{2}$ compañía», carta del teniente Abelardo Cuadra a su hermano Luciano, fechada 
diciéndole que llamase a Somoza para que se resolviera el asunto, y recordándole - según la versión aceptada por Macaulay - su calidad de "hermanos" (término cuyo uso Macaulay explica diciendo que tanto Somoza como Delgadillo y el propio Sandino eran «hermanos» masones). Persuadido por Sandino, dícese que Delgadillo telefoneó a Somoza (el cual estaba en un recital de la poetisa sudamericana Zoila Rosa Cárdenas) y que éste le dijo que no podía hacer nada, negándose a hablar directamente con Sandino. Hay diferentes versiones de algunos de los hechos (según el teniente Abelardo Cuadra, los cinco fueron detenidos y llevados al Hormiguero, y el intento de llamada se hizo desde allí, antes de que Delgadillo separara a don Gregorio y Salvatierra de los demás) ${ }^{20}$.

Los detalles precisos no importan mucho, y ya que hasta los historiadores han tenido que reconciliar sus diversas fuentes para presentar sus respectivas versiones aparentemente autoritativas, el poeta hizo bien en venir directamente al grano cuando introdujo el incidente de la llamada en su flashback; pero ¿por qué lo postergó? Con esto consiguió dos cosas: poder emplearlo ahora para subrayar el miedo atribuido a Somoza, que no tendría el valor para contestarle a Sandino en persona (conviene notar que ésta es quizá la menos lógica de las posibles explicaciones de su silencio); y haber podido condensar el último viaje de Sandino, ya que la progresiva aceleración de sus escenas hubiera sido casi imposible al haberse introducido este incidente entre su detención y el llevársele «en otro auto para otro lado» con Estrada y Umanzor (v. 336). Cabe notar asimismo una multiplicación implícita de las llamadas por parte del poeta, puesto que no se hubiera podido decir «iSandino lo llama por teléfono!» a Somoza (v. 350) sin haberse contestado el teléfono para saber quién era, y por tanto el verso «Somoza mandó no contestar el teléfono» (v. 353) tiene que referirse a una llamada posterior, la cual seguiría «repicando / y repicando» (vv. 355-356) porque esta vez se dejó sin contestar.

Tales pequeñas modificaciones de los hechos menores son fáciles de justificar: consiguen sus efectos poéticos con mucha economía, y siguen más o menos fieles al 'espíritu' de los hechos (según lo entiende el poeta) aun cuando no siguen lo ocurrido 'al pie de la letra'. Pero ha habido otra modificación de lo histórico en pro de la interpretación cardenalicia de los sucesos, la cual parece una tergiversación más tendenciosa: verbigracia, la excusa de Somoza «I was in a Concierto» (v. 344). Todas las

el 10 de octubre de 1935, reproducida por Gregorio U. Gilbert, Junto a Sandino (Edición de la Universidad Autónoma de Santo Domingo, 1979), p. 353.

${ }^{20}$ Ibid., p. 356. 
versiones que he podido consultar hasta ahora concuerdan en que Somoza estaba en aquel recital de poesía, y la vaguedad sarcástica de aquellos versos "había estado en un concierto / o en un banquete o viendo bailar a una bailarina o / quién sabe qué mierda sería» (vv. 345-347), que luego se concretaría definitivamente en la pura invención de «La bailarina seguía bailando para el asesino» (v. 354) —interpretada por John Lyons como una alusión simbólica al baile de Salomé delante de Herodes (véase nota 18) - , parece haber sido un modo más de denigrarlo frente a la dignidad enaltecida de su víctima ${ }^{21}$.

(15) Después se vuelve brevemente a la fosa, en la cual los guardias acaban de enterrar los tres cadáveres. Más económica todavía que la (13), esta estrofa no cuenta más que con treinta y tres sílabas fonéticas: once por verso (aunque el recuento prosódico del v. 357 sería de doce, dada su terminación aguda). Está compuesta exclusivamente de imágenes visuales, dentro de las cuales cabe notar la presencia de las dos luces descritas en los dos versos paralelos (v. 357, v. 359) que encierran la imagen de los «cuatro guardias [que] están cerrando un hoyo» (v. 358): su paralelismo nos devuelve del mundo atroz de los hombres al mundo más bello de la naturaleza (explorada en la larga tirada de versos que comenzará la última parte del episodio comentado) cuando la cámara se eleva - por así decirlo- de los guardias con la luz artificial de su lámpara tubular para encuadrar la bella «luna de febrero».

Con esta breve escena se da por terminado el ejemplo de acciones paralelas y montaje acelerado que yo quise analizar. Será evidente que ambos recursos son formas especiales de la yuxtaposición dialéctica de imágenes visuales: de mayor envergadura que la de Ubico en su palacio y su pueblo afuera por tratarse de la yuxtaposición ya no de tales imágenes aisladas, sino de pequeñas escenas (verbigracia, las diez distintas unidades narrativas de las diez estrofas que compusieron la secuencia

${ }^{21}$ Es posible, desde luego, que Cardenal no supiera todos los detalles (aunque cuando yo lo consulté sobre las fuentes de sus poemas históricos en Solentiname, en 1972, me dijo que el episodio de Sandino en Hora 0 estaba basado en una multiplicidad de fuentes publicadas, cuyos títulos ya no podía recordar). Si la palabra atribuida a Somoza en la fuente seguida por el poeta hubiese sido 'recital' (aplicable tanto a un concierto como a un recital de poesía), el convertirla en 'concierto' podría explicarse por el deseo de establecer el juego de palabras de los vv. 344-345 (entre "concierto» y «era cierto»). Lyons tiene una observación muy aguda con respecto a esta frase de Somoza: después de decir que probablemente estuviera en inglés por tratarse de uan excuse or protestation of innocence to the American Minister», agrega "however, the use of the word 'concierto' jars in the sentence, reminding us that Somoza is neither Nicaraguan nor American but an ugly hybrids (op. cit., p. 21). 
paralelística); pero la naturaleza de su modo de afectar al lector/espectador es siempre la misma. O sea, que el significado de los sucesos que el poeta nos ha venido mostrando no reside ni en la una ni en la otra de las dos acciones consideradas de por sí, ni tampoco en su mera suma (aunque las dos series de escenas sean las únicas cosas literalmente 'explicitadas' ante nuestros ojos), sino en un 'algo' mucho más conmovedor que permanece implícito, pero que nos ha ido saltando a la vista en los cambios de escena como resultado de aquellas repetidas contraposiciones dialécticas entre las unidades narrativas.

En la larga tirada de versos que empieza la tercera parte, en cambio, no hallaremos ni siquiera el montaje dialéctico de sencillos pares de imágenes contrastantes (como hubo en el 'introito' del poema), sino un montaje de imágenes paralelas cuya pausada acumulación va reforzando la tranquilidad de la naturaleza en la transición desde los oscuros sucesos de aquella noche triste a la luz del próximo día. Vendrá otro ejemplo de montaje de choque, sin embargo, cuando el poeta nos obliga a volver de la mañana campesina de la estrofa (16) a los punibles lugares de la capital, en la (17), para después rematar el episodio de Sandino con dos pares de versos cuyo sentido literal se trueca irónicamente en un comentario de brutal sarcasmo poético: sobre lo sucedido, a la vez que sobre la razón de Estado de Somoza.

\section{TERCERA PARTE}

(16) 360 Es hora en que el lucero nistoyolero de Chontales levanta a las inditas a hacer nistoyol, y salen el chiclero, el maderero y el raicillero con los platanales todavía plateados por la luna,

364 con el grito del coyote solo y el perico melero y el chiflido de la lechuza a la luz de la luna. La guardatinaja y la guatuza salen de sus hoyos y los pocoyos y cadejos se esconden en los suyos.

368 La Llorona va llorando a la orilla de los ríos: «¿Lo hallaste?» «¡No!» «¿Lo hallaste?» « No!» Un pájaro se queja como el crujido de un palo, después la cañada se calla como oyendo algo.

$372 \mathrm{Y}$ de pronto un grito... El pájaro pronuncia la misma palabra triste, la misma palabra triste. Los campistos empiezan a totear sus vacas: Tóoo-tó-tó-tó; Tóoo-tó-tó-tó; Tóoo-tó-tó-tó;

376 los lancheros levantan las velas de sus lanchas; el telegrafista de San Rafael del Norte telegrafía: 
BUENOS DIAS SIN NOVEDAD EN SAN RAFAEL DEL NORTE y el telegrafista de Juigalpa: SIN NOVEDAD EN JUIGALPA.

380 Y las tucas van bajando por el Río Escondido con los patos gritando cuá-cuá-cuá, y los ecos, los ecos, mientras el remolcador va con las tucas resbalando sobre el verde río de vidrio

384 hacia el Atlántico...

Y mientras en los salones del Palacio Presidencial y en los patios de las prisiones y en los cuarteles y la Legación Americana y la Estación de Policía

388 los que velaron esa noche se ven en el alba lívida con las manos y las caras como manchadas de sangre.

«I did it», dijo después Somoza. «I did it, for the good of Nicaragua.»

392 Y William Walker dijo cuando lo iban a matar: «El Presidente de Nicaragua es nicaragüense.»

\section{Breve comentario a la Tercera parte}

(16) Esta evocación de la frescura y apacibilidad de la naturaleza al acercarse el alba, y de su consonancia con la tranquilidad campesina de las actividades matutinas de los hombres lejos de la capital, sigue siendo eminentemente cinematogénica. Se subdivide en tres partes: primero, ocho versos totalmente apacibles (vv. 360-367), sin recuerdo alguno de la tragedia de la noche, hasta que la mención de la «guardatinaja» saliendo de su hoyo (v. 366) nos hace recordar la guardatinaja metafórica del verso 297, cuyo entierro en otro hoyo acabamos de presenciar; segundo, una pequeña secuencia audiovisual (vv. 368-373), en la que la naturaleza misma parece lamentar la muerte de Sandino con el triste canto repetido «¿Lo hallaste?» «¡No!» del pájaro llamado La Llorona (con todas las asociaciones tristes de la canción tradicional del mismo nombre); y, tercero, otros once versos en donde la gente ya se pone a trabajar (versos 374-384).

Dije que esta escena seguía siendo "eminentemente cinematogénica»: de hecho, sus veinticinco versos contienen nada menos que diecisiete imágenes visuales para el camarógrafo, con doce indicaciones auditivas a partir de «el grito del coyotesolo» (v. 364). O sea, que aquí se nos hace pensar en una banda sonora mucho más que en cualquiera de las quince escenas anteriores, una banda sonora cuyas indicaciones se subdi- 
viden en seis grupos: a) los últimos sonidos de la noche (vv. 364-365); b) la tristeza de ciertos pájaros en la madrugada (vv. 368-373); c) el «Tóoo-tó-tó-tó» repetido de los campistos empezando «a totear sus vacas» (vv. 374-375); d) las transmisiones matutinas de los dos telegrafistas, con sus (implícitos) manipuladores traqueantes (vv. 377-379); e) otra vez pájaros — «los patos gritando cuá-cuá-cuá» (v. 381)—; y finalmente f) los ecos del remolcador (vv. 381-382), que se van repitiendo, tal como se van repitiendo los ecos de la muerte de Sandino en nuestra mente. Cardenal sabe emplear tales sonidos muy diestramente, y ya vemos aquí —en el «¿Lo hallaste?» «¡No!» «¿Lo hallaste?» «iNo!» de La Llorona (v. 368) — su modo característico de aprovechar las verbalizaciones de los gritos y los trinos de los pájaros, tan populares entre la gente del campo. Años después, llevaría este último recurso a su extremo en el Canto nacional (1972), el cual termina en nueve versos compuestos enteramente de tales gritos y trinos de las aves.

(17) Después de aquella evocación de la convivencia armoniosa entre los hombres y la naturaleza tierras adentro, vienen los cuatro versos largos y pesados que nos devuelven brutal y abruptamente a la pesadilla de la capital violenta, con sus dejos de paisaje anímico en aquella «alba lívida» que va manchando «las manos y las caras» de todos «los que velaron esa noche» como «de sangre» (vv. 388-389). Luego:

(18) La segunda excusa de Somoza, que ya no es una pura excusa, sino al mismo tiempo un intento de autojustificación. Antes no se le podía inculpar porque había estado «in a Concierto» (v. 344); esta vez, y de nuevo en inglés, el egoísmo apenas disfrazado de su apelación a la razón de Estado: «I did it, for the good of Nicaragua» (v. 391).

(19) Después vienen los dos últimos versos, de sentido algo oscuro para quienes no conozcan bien la historia de Nicaragua: William Walker era el filibustero norteamericano que se apoderó de Nicaragua en 1855 a la cabeza de cincuenta y ocho mercenarios — «The American Phalanx of Immortals»- haciéndose "elegir' presidente el año siguiente, para morir fusilado por las autoridades hondureñas el 12 de septiembre de $1860^{22}$.

${ }^{27}$ Véanse Eduardo Crawley, Dictators Never Die: A Portrait of Nicaragua and the Somozas (Londres, 1979), pp. 32-33; Millett, op. cit., pp. 18-19. El poema de Cardenal "Con Walker en Nicaragua» (Revista Conservadora del Pensamiento Americano, Nos. 85-86, 1967, pp. 87-95; Papeles de Son Armadans, No. 88, 1971, pp. 138-154) fue el primer poema que escribió después de su regreso a Nicaragua en 1950. 
Sí que dijo «El Presidente de Nicaragua es nicaragüense» cuando lo iban a matar, pero citarlo aquí es la suprema ironía. Me parece implicar tres cosas: a) que Somoza era tan filibustero - y tan mentiroso- como é1; b) que la 'elección' de Somoza García a la presidencia en 1936 iba a ser tan fraudulenta como la suya, y c) que, bien mirado, Somoza García era tan poco «nicaragüense» como él -0 , si se quiere, tan norteamericano como él- al estar igualmente al servicio de los intereses de los Estados Unidos. Este último significado de dicha yuxtaposición de imágenes queda subrayado por un recurso irónico adicional: la ironía linguística de que Walker se nos dirige en español, mientras Somoza se nos había dirigido en inglés. Ambos han estado empleando una lengua extranjera, aprendida para ponerla al servicio de sus mentiras. Pero no todo esto se puede deducir instantáneamente de la yuxtaposición de estas dos últimas estrofas, y mientras la imagen audiovisual de Somoza en la (18) remataría el guión de nuestra película documental hipotética de modo eficaz, el sentido de la imagen de Walker depende de una compleja red de asociaciones histórico-literarias no explicitadas, las cuales no pueden 'saltar a la vista' de ningún lector/espectador de la mera yuxtaposición paralelística de los dos dictadores pronunciando sus mentiras respectivas ${ }^{23}$.

Con esto se da por terminado el comentario más o menos propiamente 'cinematográfico' de la segunda mitad de este segundo episodio de Hora 0 . Quisiera insistir en que no he querido insinuar (jni siquiera implícitamente!) que la poesía de Ernesto Cardenal haya sido influida directamente por algunos de los procedimientos del montaje cinematográfico, ni que el poeta hubiera estado pensando en escribir un poema que tuviese el carácter de guión para un documental sobre la historia de Nicaragua, aunque sería bien fácil emplear su poema con tal fin. El mismo introdujo una analogía fílmica en aquella entrevista de Los poetas comunicantes, pero sólo lo hizo para explicar aquella teoría poundiana (acerca del parentesco entre sus imágenes poéticas y los ideogramas chinos) a cuantos quizá no comprendieran la analogía tan erudita del propio Pound. Entonces - pero sólo entonces- explicó su propio modo de ver la influencia de Pound sobre su propia poesía:

Algunos han hablado en América Latina de la sobriedad de mi poesía, de que he renunciado a los adornos, de que es una poesía directa, etc. No es más que una aplicación de esas enseñanzas de Pound,

${ }^{23}$ La imagen de Walker sólo se podría emplear con eficacia en dicha "documental hipotética' si sus antecedentes esenciales se hubieran establecido en la pantalla anteriormente. 
en el sentido de hacer la poesía superponiendo las imágenes unas con utras, sin recurrir a ningún otro efecto de lenguaje, pues no se hace necesario ${ }^{24}$.

Es verdad que hay muchos otros 'efectos del lenguaje' en su poesía, pero es cierto asimismo que la técnica de la yuxtaposición dialéctica de imágenes visuales viene a ser su recurso predilecto, y también es obvio que la 'sobriedad' de su 'poesía directa' se debe principalmente al haberla despojado de los adornos metafóricos tradicionales para realzar la nitidez de dichas imágenes.

Si he querido llevar aquella analogía con «lo que hace el cine» mucho más allá de lo que hiciera Cardenal, ha sido para obligar al lector de Hora 0 a reconocer su carácter extraordinariamente visual, imponiéndole la necesidad de convertirse en un lector/espectador dispuesto a visualizar todo lo expuesto con la ayuda de sus ojos interiores (como quien iniciase uno de los ejercicios espirituales ignacianos haciéndose una buena composición de lugar). De ahí el comentario 'cinematográfico' en que se fueron dilucidando todos sus modos de emplear recursos visuales - $-\mathrm{y}$ muchas veces audiovisuales-en aquellos ciento quince versos de Hora 0.

Creo que Cardenal está empleando tales procedimientos para conseguir la incorporación de sus lectores en dos procesos bien distintos: a) en el mismo proceso poético, ya que quien lee un poema como Hora 0 no puede limitarse a escucharlo, sino que tiene que participar -que 'co-laborar' - en dicho proceso, reaccionando activamente ante las diversas yuxtaposiciones de imágenes pares o dispares ('careándolos', como diría un conceptista del Siglo de Oro, no sólo entre sí, sino también con todo lo que se ha dejado de explicitar) y haciendo lo mismo con las series de escenas contrastantes que se le presentan ${ }^{25}$, y $b$ ) en el proceso ideológico-político del compromiso que anima el texto de todo verdadero 'poema comprometido' como Hora 0 , exigiendo una toma de conciencia de todo lector dispuesto a escuchar al poeta, en la esperanza de que ésta le haya de conducir hacia una verdadera toma de posición que le colocaría codo con codo al lado del poeta, en su 'lucha' para lo que sea (verbigracia, para librar a Nicaragua de todos los Somozas, en el caso concreto de Hora 0). Este es el fin, y el primer proceso (el poético) no es más que el medio escogido para conseguirlo. En Hora O Cardenal procede por la yuxtaposición de imágenes: otros poetas compro-

${ }^{24}$ Benedetti, op. cit., p. 102.

${ }^{25} \mathrm{La}$ visualización de lo presentado en un poema requiere la colaboración activa del lector, mientras las imágenes de una película se presentan a los ojos del espectador, entrándole por la vista sin exigir más que una receptividad pasiva. 
metidos emplean otros medios, pero siempre están poniendo su medio literario al servicio del mensaje sociopolítico que desean transmitir ${ }^{26}$.

En vista de la seriedad de tal propósito, cabe terminar este trabajo con algunas consideraciones sobre el modo de tratar y matizar la historia al irla transformando en poesía, en el caso concreto de Hora 0. Al examinar las diecinueve estrofas comentadas, vimos varias pequeñas modificaciones de la realidad: a) la condensación de dos años en uno, de modo que el lector pudiera fácilmente creer que Sandino estaba llegando a Managua casi a continuación de la firma del desarme; b) la condensación de dos conversaciones en una, colocando lo dicho por Calderón Ramírez en boca de Somoza; c) la insinuación de la complicidad del general Moncada; d) el dejarnos creer que todas las menciones del «Ministro Americano" se referían al mismo individuo; e) la curiosa imprecisión acerca del paradero de Somoza durante el asesinato, que permite la entrada de la voz sarcástica del poeta en aquel «quién sabe qué mierda sería»; f) la 'bailarina' aparentemente ficticia, introducida de un modo literal para conseguir un efecto puramente simbólico. $Y$ a estos cambios pudiérase agregar que la eficacia del terceto que termina en «¡Fuego!» se obtuvo mediante una doble modificación del desenlace histórico: no hubo ningún grito de «iFuego!», pues parece que Delgadillo dio la orden de abrir fuego disparando su pistola al aire; mientras los últimos minutos de Sandino no fueron tan breves como se sugiere, ya que éste hizo todo lo posible para postergar su ejecución (pidiendo agua y luego pidiendo permiso para orinar) en la esperanza de que algo -0 alguien - aún podría intervenir, pero cada petición fue rechazada, hasta que su compañero Estrada terminó diciéndole que no pidiese nada más ${ }^{27}$.

Tales cambios son mucho menores que los que se pueden constatar

${ }^{26}$ Véanse Pring-Mill, «The Scope of Spanish-American Committed Poetry» (Homenaje a Rodolfo Grossmann, Francfurt am Main-Berna-Las Vegas, 1977), pp. 259333 ( $\mathrm{y}$ reimpresión en folleto aparte, Oxford, 1978); ídem, «The nature and the functions of Spanish American poesia de compromisos, The Search for Identity in Latin American Literature, ed. Robert Gurney (Bulletin of the Society for Latin American Studies, No. 31, 1979), pp. 4-21.

${ }^{27}$ Véase la carta siguiente de Abelardo Cuadra, fechada el 23 de octubre de 1935, reproducida en G. U. Gilbert, op. cit., pp. 358-363. Su tercera carta, del 3 de noviembre, cuenta el entierro de los cadáveres, y el detalle «Cuando se ponía la luna echaban las últimas paladas de tierra» pudiera haber inspirado los vv. 358359 (el testimonio de Abelardo Cuadra ya se había dado a conocer años antes de la composición de Hora 0 , aunque sus cartas se citen aquí según la edición dominicana de 1979), p. 369. La cuarta y última carta de Abelardo Cuadra, fechada el 14 de noviembre (ibid., pp. 370-372), cuenta la quema del archivo personal del General de Hombres Libres por Somoza García «unos ocho días después de la muerte de Sandino», p. 370. 
en cualquier película histórica de ficción semidocumental, como Viva Zapata, y es evidente que todos fueron verdaderos logros poéticos: mejoramientos de la realidad, por así decirlo. Sería fácil, por tanto, limitarnos a observar que las demandas de ser fiel a la verdad poética habían prevalecido sobre aquéllas de ser absolutamente fiel a la verdad histórica. Pero esto ¿qué quiere decir? Suena a pura retórica en nuestros días, pero en el contexto de teorías literarias pasadas de moda muchos años ha, tendría pleno sentido y valdrá la pena citar a un teórico del siglo XVII a este propósito:

No es oficio del poema narrar los casos sucedidos propiamente como sucedieron, sino como pudieron suceder verosímil o necesariamente. Por donde viene a ser la poesía más excelente que la historia; y la causa es porque aquélla mira a objeto universal y ésta particular. De aquí se echa de ver que tomando un suceso como naturaleza lo comenzó y acabó, le hallaremos muchas imperfecciones, y ésas es menester enmendarlas con el arte, y perfeccionarlas de manera que no le falte circunstancia necesaria para que aquella obra parezca y sea consumada. Pues esta licencia que tiene el poeta para quitar y poner en la obra de naturaleza, se llama ficción poética...28.

Francisco Cascales, el autor de estas palabras, escribía para un público igualmente culto, que ya conocería la distinción aristotélica entre historia y poesía: la función de aquélla era precisamente «narrar los casos sucedidos propiamente como sucedieron» —en toda su particularidad- mirando siempre por lo verdadero, guiado por el concepto de la veracidad; pero la función de la poesía era 'imitar' lo 'universal' - lo cual implica representar las cosas no 'tales como son', sino 'tales como debieran de ser'- mirando siempre por la más perfecta verosimilitud.

Nuestras categorías ya no son las mismas, pero el problema de la refundición poetizada de lo histórico no se ha marchado. Se me dirá, quizá, que no hay problema, que está bien claro que hay que preferir lo verosímil a lo verdadero, puesto que gran parte de la eficacia de un poema depende de la verosimilitud de la ficción poética (y es cierto que un texto puede no mentir y seguir siendo, sin embargo, un mal poema).

${ }^{28}$ Francisco Cascales, «En defensa de las comedias y representación de ellas», Cartas filológicas (Ed. Clásicos Castellanos, 1934, II, p. 59; pasaje citado por A. A. Parker, «History and poetry: the Coriolanus theme in Calderón», Hispanic Studies in Honour of I. González Llubera (Oxford, 1959, nota 3). Véase PringMill, «Calderón de la Barca y la fuerza ejemplar de lo poetizado», a publicarse en las actas del Sexto Congreso Anglogermano sobre Calderón, celebrado en Würzburg en 1981 . 
Pero ¿qué pasa cuando estamos hablando de un poema cuyo carácter documental le da todas las apariencias de ser un reportaje histórico (un testimonio fidedigno acerca de lo sucedido en tal lugar, en tales fechas)? Es fácil estar tan convencido por lo verosímil que se termine tomando la verosimilitud por la veracidad.

Habrá poetas que confundan la historia con la poesía (es fácil creer que basta narrar verdades para crear poesía, y la poesía comprometida está llena de textos que comprueban que esto no funciona). Este no es el caso de Cardenal: poeta bien consciente de su oficio. Pero también hay que pensar en el lector. No todos los lectores de la poesía de compromiso son tan cultos como Cardenal; y aunque lo fueran, su poema es tan eficaz y convincente, que es fácil creer que el poeta haya narrado "los casos sucedidos propiamente como sucedieron" (sobre todo cuando el carácter 'documental' del poema se refuerza mediante la incorporación de documentos, en los vv. 285-296). No sólo es fácil, sino natural, y es de suponer que el lector que no coteja el poema con los hechos seguirá creyéndolo. Se me dirá que la 'culpa' - si la hay- es del lector, y que éste tiene que ser muy ingenuo si insiste en confundir la poesía con la historia. No hay tal: creerse lo verosímil no es ingenuo, y el que un lector confunda los dos géneros tampoco lo es si los poetas que lee le han hecho creer -o le han dejado creer- que sus textos poéticos tenían el carácter de documentación histórica. La poesía de compromiso narrativa tiene cierto carácter testimonial para la mayoría de sus lectores, lo cual impone ciertas responsabilidades extrapoéticas sobre quienes la escriben ${ }^{29}$.

${ }^{29}$ Otros aspectos del problema se tratan en Pring-Mill, «Las transformaciones de la realidad en la poesía de compromiso hispanoamericana» (ponencia presentada en el Deutscher Hispanistentag 1981), y «Ernesto Cardenal y la fuerza ejemplar de lo poetizado» (comunicación presentada en el XX Congreso del Instituto Internacional de Literatura Iberoamericana, Budapest, 1981). 